\title{
The Effect of Mathematics Subject on Accounting Students of Private and State Universities in Iran
}

\author{
Mahdi MORADI* \\ Mahdi SALEHI** \\ Somayeh KHALILIANMOVAHED ${ }^{* * *}$
}

\begin{abstract}
It is proved that mathematics ability effect on understanding in principles of accounting in some research but number of these investigations is very low. The main purpose of this research is to explore the relationship between influence of mathematics ability on understanding in principles of accounting through investigating relationship between students score in principle of accounting lesson and students score on mathematics pre-test and math score. Statistical sample consists of 184 own state university's students and 105 private university's students that they had selected principle of accounting lesson, involved 120 accounting fields students, 84 management students and 85 economic students. Pre-test only involve areas of mathematics that have more impact on understanding in principles of accounting. Results showed students arithmetical skills are high in both universities and conceptual skills in own state university and algebra skills in private university are low and mathematics skills has a significant effect on principles of accounting score. In addition, students' self-confidence beliefs and its impact on students score in mathematics and principles of accounting lessons were explored. Results showed students who had high level of self-confidence had gotten better scores.
\end{abstract}

Keywords: skills, principles of accounting, math pre-test, selfconfidence.

\footnotetext{
* Associate Professor of Accounting, Ferdowsi University of Mashhad, Mashhad, Iran

** Assistant Professor of Accounting, Ferdowsi University of Mashhad, Mashhad, Iran, E-mail: mahdi_salehi54@yahoo.com

${ }^{* * *}$ Ferdowsi University of Mashhad, Mashhad, Iran.
} 


\section{INTRODUCTION}

Mathematics knowledge has prepared suitable facilities such as presentation precise analysis, relationship description between phenomenon and decreasing prediction error in different science. Indeed, most of accounting variables are numerical then mathematical conceptions were expanded in accounting. One of the main goals of mathematics education is to increase understanding, analyzing, and expansion of scientific and creative thinking. Historically accounting has been based on mathematics knowledge. Loca Pachioly believed that with using of math view of point could present logic for debt and credit rules. By learning mathematics will get dynamic to principles of accounting studying, expand abilities, and create a critical analysis (Warsono, Darmawan, and Ridha, 2009).

Since accounting course in Iran country is accepted of four high school fields (mathematics, empirical science, human science and technical) therefore students abilities in mathematics would be different that might affect on their successful in principles of accounting then they should schedule for this matter to improve their abilities (Gary, 2008). Gender differences in mathematics achievement and differences in participation amount girls and boys in advanced mathematics courses were heard hence gender equality in mathematics achievement sound still unlikely. Selfconfidence in mathematics achievement does not clear and seems be different in girls and boys. Thus, impact of self-confidence was explored in principles of accounting and mathematics lessons. Results showed students who had higher level of self-confidence got better scores.

\section{Review of Related Literature}

Accounting defines operational conceptions by use of numerical contexts (Yunker, Yunker, Krull, 2009). Mathematics abilities are investigated in order to create better understanding of accounting problems and financial statements analysis. It seems accountants who have higher level of mathematics abilities are more successful than others are. Students who have arithmetic and algebra skills would understand accounting better (Pritchard, Romeo, and Saccucci, 2000). Students who passed advanced mathematics course generally had better performance in accounting and elementary business courses (Alcock, Cockcroft, and Finn, 2008). Ballard and Johnson (2004) explored mathematics affects on economic course. Their goal was determination students' performance in math pre-test (As a predictor progressing in economic course). They described math pre-test can determine relationship between students performance in economic lesson 
and various mathematics operations. Rainsbury and Darroch (2009) proved logic was applied in accounting double equation determine its elements. They described place of assets and costs with usage mathematics logic is explainable. Debt and credit rules are completely base on mathematics logic and they suggested that accounting learning should be performed by using a mathematics view point.

Empirical observations show that there is relationship between self confidence and progressing. Students who had high level of self confidence were earned higher scores in performing homework and examination that relate to writing.

Students with less self confidence believe that they are disabling. When students expected desirable results and positive valuation of themselves will improve their performance. Rainsbury and Darroch (2009) described students who self confidence about their mathematics abilities had got better score toward students who had no self confidence. But this matter did not prove in their research they suggested students mathematics abilities should be examined to determine weakness that is in their mathematics knowledge and necessary decisions for fulfilling this gap. Meelissen and Luyten (2008) showed gender differences are decreasing in mathematics learning. Participation rate of girls in advanced mathematics courses in several country shows gender equality still is unlikely. They concentrated over influential factors on sexual differences in mathematics achievement (selfconfidence, the interest value of mathematics, the attainment value of mathematics and gender stereotyped views of mathematics). Results showed gender differences that relate to self-confidence in mathematics achievement are more important than other factors.

\section{Research Methodology}

Method is used in this research is empirical. After beginning semester a math pre-test was given to students who had selected principles of accounting lesson. Examination questions involved special areas that correlated with accounting. Students were not allowed to use of calculator for responding. At the end of semester, each of student's performance in math score and math pre-test score was compared with principles of accounting course.

Questionnaire consists of three parts as below: involves:

The first section is related to demographic and situational information

- $\operatorname{Sex}($ female $=1$, male $=0)$

- Class $($ fresh $=1$, to senior $=4)$ 
- Course $($ accounting $=1$, management $=2$, economic $=3)$

- Age $($ under $18=1$ to over $23=4)$

Since principles of accounting lesson is presented for management and economic fields, therefore impact of this factor is considered in this research.

Second section includes questions that related to students course in high school and students self-confidence in mathematics and principles of accounting courses.

Table1. Descriptive Statistic

\begin{tabular}{|c|c|c|c|c|c|}
\hline VARIABLES & EXPLANATION & & STD. DEV & MEAN & $\mathrm{N}$ \\
\hline \multirow[t]{2}{*}{$\mathrm{S}$} & \multirow[t]{2}{*}{ Sex } & Own State & 0.476 & 0.66 & 184 \\
\hline & & Private & 0.486 & 0.63 & 105 \\
\hline \multirow[t]{2}{*}{$\mathrm{SA}$} & \multirow[t]{2}{*}{ Self confidence in accounting } & Own State & 0.826 & 2.58 & 184 \\
\hline & & Private & 0.910 & 2.46 & 105 \\
\hline \multirow[t]{2}{*}{$\mathrm{SM}$} & \multirow{2}{*}{$\begin{array}{l}\text { Self confidence in } \\
\text { mathematics }\end{array}$} & Own State & 0.890 & 2.66 & 184 \\
\hline & & Private & 0.930 & 2.78 & 105 \\
\hline \multirow[t]{2}{*}{$\mathrm{A}$} & \multirow[t]{2}{*}{ Age } & Own State & 0.466 & 2.08 & 184 \\
\hline & & Private & 0.570 & 3.10 & 105 \\
\hline \multirow[t]{2}{*}{$\mathrm{C}$} & \multirow[t]{2}{*}{ Class } & Own State & 0.180 & 2.02 & 184 \\
\hline & & Private & 0.738 & 2.89 & 105 \\
\hline \multirow[t]{2}{*}{$\mathrm{hiC}$} & \multirow[t]{2}{*}{ High school course } & Own State & 0.818 & 2.05 & 184 \\
\hline & & Private & 0.974 & 2.69 & 105 \\
\hline \multirow[t]{2}{*}{$\mathrm{UnC}$} & \multirow[t]{2}{*}{ University course } & Own State & 0.810 & 2 & 184 \\
\hline & & Private & 0.233 & 1.06 & 105 \\
\hline \multirow[t]{2}{*}{ PSCORE } & \multirow{2}{*}{$\begin{array}{l}\text { Principles of accounting } \\
\text { score }\end{array}$} & Own State & 3.413 & 14.96 & 184 \\
\hline & & Private & 2.600 & 16.17 & 105 \\
\hline \multirow[t]{2}{*}{ MSCORE } & \multirow[t]{2}{*}{ Mathematics score } & Own State & 3.265 & 14.889 & 184 \\
\hline & & Private & 3.062 & 15.60 & 105 \\
\hline \multirow[t]{2}{*}{ MPSCORE } & \multirow[t]{2}{*}{ Math pre-test score } & Own State & 4.308 & 0.856 & 184 \\
\hline & & Private & 0.184 & 0.480 & 105 \\
\hline \multirow[t]{2}{*}{ MPSCORE-1 } & \multirow{2}{*}{$\begin{array}{l}\text { Math pre-test score1- } \\
\text { arithmetic }\end{array}$} & Own State & 3.704 & 0.925 & 184 \\
\hline & & Private & 0.235 & 0.563 & 105 \\
\hline \multirow[t]{2}{*}{ MPSCORE-2 } & \multirow{2}{*}{$\begin{array}{l}\text { Math pre-test score2- } \\
\text { percentages and proportions }\end{array}$} & Own State & 1.858 & 0.787 & 184 \\
\hline & & Private & 0.239 & 0.477 & 105 \\
\hline \multirow[t]{2}{*}{ MPSCORE-3 } & \multirow[t]{2}{*}{ Math pre-test score3-algebra } & Own State & 1.789 & 0.853 & 184 \\
\hline & & Private & 0.240 & 0.40 & 105 \\
\hline \multirow[t]{2}{*}{ MPSCORE-4 } & \multirow{2}{*}{$\begin{array}{l}\text { Math pre-test score4- } \\
\text { conceptions }\end{array}$} & Own State & 2.174 & 0.644 & 184 \\
\hline & & Private & 0.214 & 0.469 & 105 \\
\hline
\end{tabular}

Third section composed of 24 math questions that responding time to this math pre-test is 25 minutes. 24 items was divided as below: 
- 8 items involving principally arithmetic.

- 8 items involving principally percentages and proportions.

- 8 items involving principally algebra.

Arithmetical operations include addition, subtraction, multiplication and division.

Percentages and proportions operations on fractional numbers.

Algebra includes algebraic solution for an unknown X.

According another categorizing, questionnaire consists of:

- 9 items involving substantial conceptions.

- 15 items not involving substantial conceptions.

Substantial conceptions include 2 arithmetic items, 4 percentages and proportions items and 3 algebra items. The questionnaire was completed by 184 own state university's students and 105 Private university's students who had selected principles of accounting lesson that involved 9 class and was thought by 8 various teachers. A questionnaire administrated among the students and considered 25 minutes for responding. Students were not allowed to use of calculator.

Table 1 shows numbers of students who had selected principles of accounting course. In the current study, the questionnaire adopted from Yunker, Yunker and Krull (2009) questionnaire.

The mean math pre test score in Table1 indicates questions percentage answered correctly. The lowest of five score in own state university is MPSCORE4 (0.644) pertaining to conceptions but in private university is MPSCORE3 (0.40), while the highest score in own state university is MSCORE1 (0.925) pertaining to arithmetic items and in private university is also MSCORE 1 (0.563). Table 2 shows results of chi square test among demographic variables. According this table kind of university, students who have achieved above fifteen are considered good otherwise bad. Statistics show own state university $(69.5 \%)$ generally has better than scores private university (55.4). females in comparing male have achieved better than scores $(63.4 \%)$. Students who have the higher self-confidence in accounting and mathematics, they achieved the better scores. According to table students who their age is below 18 they achieved better scores. As results show students in forth class have the best scores (72.4) because they had more than skills in accounting and mathematics in comparing others. Students who their high school course were mathematics achieved the best scores (80.6) while, empirical, human and technical have achieved the lowest scores respectively. University course has a significant effect on principles of accounting score. Accounting course has the best scores (68.50) among other courses. 
Table 3 shows correlation matrix among research important variables that contain principles of accounting score and mathematics abilities variables involve mathematics score and math pre-test 1 to pre-test 4 . When two variables have closely, correlated coefficients indicate a warning sign that multicollinearity may affect on the results. When correlation between two variables is a lot distinguish of separation effects will be hard. Totally, when correlation coefficients between two variables be more than 0.5 indicate that multivariate might affect on results. The highest correlation in own state university is between MPSCORE and MPSCORE4 (0.819) so is in private university (0.898). The lowest correlation is between MPSCORE 1 and principles of accounting score $(0.252)$ but in private university is between MPSCORE1 and MPSCORE3 (0.287).

Table 2. Cross tabulation

\begin{tabular}{llccc} 
& & & \multicolumn{2}{c}{ Principle Score } \\
\cline { 4 - 5 } variables & & Number & Good (\%) & Bad (\%) \\
\hline Kind of university & Own state & 184 & 69.5 & 44.6 \\
S & Private & 105 & 55.4 & 30.5 \\
& Male & 101 & 63.4 & 41 \\
SA & Female & 188 & 59 & 36 \\
& Good & 141 & 77.3 & 22.7 \\
& Normal & 117 & 53 & 47 \\
SM & Bad & 31 & 12.9 & 87.1 \\
& Good & 119 & 73.1 & 26.9 \\
& Normal & 121 & 62 & 38 \\
A & Bad & 49 & 26.5 & 73.5 \\
& Below18 & 56 & 69.6 & 30.4 \\
& 18-19 & 79 & 57 & 43 \\
& 20-23 & 121 & 57.9 & 42.1 \\
C & Above23 & 33 & 63.6 & 36.4 \\
& First & 120 & 57.1 & 42.9 \\
& Second & 115 & 61.1 & 38.9 \\
& Third & 43 & 58.8 & 41.2 \\
hiC & Forth & 19 & 72.4 & 27.6 \\
& Mathematic & 73 & 80.6 & 19.4 \\
& Empirical & 92 & 71.7 & 28.3 \\
& Human & 93 & 67.1 & 32.9 \\
uniC & Technical & 31 & 37.6 & 62.4 \\
& Accounting & 162 & 68.5 & 31.5 \\
& Management & 62 & 61.3 & 38.7 \\
& Economic & 64 & 39.1 & 60.9 \\
\hline
\end{tabular}

Statistical method was applied in this study is general linear model (GLM). UNIANOVA for univariate analyses provides regression analysis and analysis of variance for one dependent variable by one or more factors 
and/or variables. By this method is estimated incrementally explanatory power of variables: principles of accounting and mathematics ability. At the first relationship between PSCORE and MSCORE with demographic variables are explored. Second, affect of demographic variables and MSCORE was considered with PSCORE. At the end, incremental explanatory of PSCORE and MPSCORE was analyzed.

Table 3. Correlation matrix

\begin{tabular}{|c|c|c|c|c|c|c|c|c|}
\hline & & $\begin{array}{c}\mathrm{P} \\
\text { score }\end{array}$ & $\begin{array}{c}\text { M } \\
\text { score }\end{array}$ & Mpscore & $\begin{array}{c}\text { Mpscore- } \\
1 \\
\end{array}$ & $\begin{array}{c}\text { Mpscore- } \\
2 \\
\end{array}$ & $\begin{array}{c}\text { Mpscore- } \\
3 \\
\end{array}$ & $\begin{array}{c}\text { Mpscore- } \\
4 \\
\end{array}$ \\
\hline \multirow[t]{2}{*}{ p score } & $\begin{array}{l}\text { Own } \\
\text { State }\end{array}$ & 1 & & & & & & \\
\hline & Private & 1 & & & & & & \\
\hline \multirow{2}{*}{ M score } & $\begin{array}{l}\text { Own } \\
\text { State }\end{array}$ & 0.549 & 1 & & & & & \\
\hline & Private & 0.689 & 1 & & & & & \\
\hline \multirow[t]{2}{*}{ Mpscore } & $\begin{array}{l}\text { Own } \\
\text { State }\end{array}$ & 0.387 & 0.474 & 1 & & & & \\
\hline & Private & 0.506 & 0.51 & 1 & & & & \\
\hline \multirow{2}{*}{$\begin{array}{l}\text { Mpscore- } \\
1\end{array}$} & $\begin{array}{l}\text { Own } \\
\text { State }\end{array}$ & 0.252 & 0.296 & 0.782 & 1 & & & \\
\hline & Private & 0.352 & 0.296 & 0.699 & 1 & & & \\
\hline \multirow{2}{*}{$\begin{array}{l}\text { Mpscore- } \\
2\end{array}$} & $\begin{array}{l}\text { Own } \\
\text { State }\end{array}$ & 0.380 & 0.324 & 0.815 & 0.499 & 1 & & \\
\hline & Private & 0.36 & 0.347 & 0.818 & 0.34 & 1 & & \\
\hline \multirow{2}{*}{$\begin{array}{l}\text { Mpscore- } \\
3\end{array}$} & $\begin{array}{l}\text { Own } \\
\text { State }\end{array}$ & 0.315 & 0.503 & 0.791 & 0.426 & 0.459 & 1 & \\
\hline & Private & 0.458 & 0.536 & 0.796 & 0.287 & 0.547 & 1 & \\
\hline \multirow{2}{*}{$\begin{array}{l}\text { Mpscore- } \\
4\end{array}$} & $\begin{array}{l}\text { Own } \\
\text { State }\end{array}$ & 0.372 & 0.434 & 0.819 & 0.519 & 0.788 & 0.644 & 1 \\
\hline & Private & 0.53 & 0.432 & 0.898 & 0.587 & 0.74 & 0.75 & 1 \\
\hline
\end{tabular}

Most of correlation coefficient among the MSCORE variables is above 0.5 it is found should not be entered more than of one in equation regression. The lowest correlation coefficient in own state university is between MSCORE1 and PSCORE (0.252) but in private university is between MPSCORE1 and MPSCORE3 (0.287).

Table 4 shows estimations of the incremental explanatory power of dependent variable, principles of accounting score and demographic variables that in own state university equals 0.336 and in private university equals 0.684 and shows general linear model's results of equation as below: $\mathrm{UnC}$

PScore $=\beta 1+\beta 2 \mathrm{G}+\beta 3 \mathrm{SA}+\beta 4 \mathrm{SM}+\beta 5 \mathrm{~A}+\beta 6 \mathrm{Y}+\beta 7 \mathrm{hiC}+\beta 8$

PScore $=$ principles of accounting score 
$\mathrm{G}=\operatorname{sex}($ female $=1$, male $=0)$

$\mathrm{SA}=$ self confidence in accounting

$\mathrm{SM}=$ self confidence in mathematics

$\mathrm{A}=$ age (under $18=1$ to over $23=4$ )

$\mathrm{C}=$ class

hiC $=$ high school course

UnC $=$ university course

The R-squared statistic in own state university 0.336 indicates 33.6 percent of total variation in the dependent variable and in private university is 0.684 ; Pscore is statistically associated with variation in the demographic variables. By respect to p-value in Table 3 can be found which variables have significant affect on dependent variable.

Table 4. Demographic variables affect on principles of accounting score

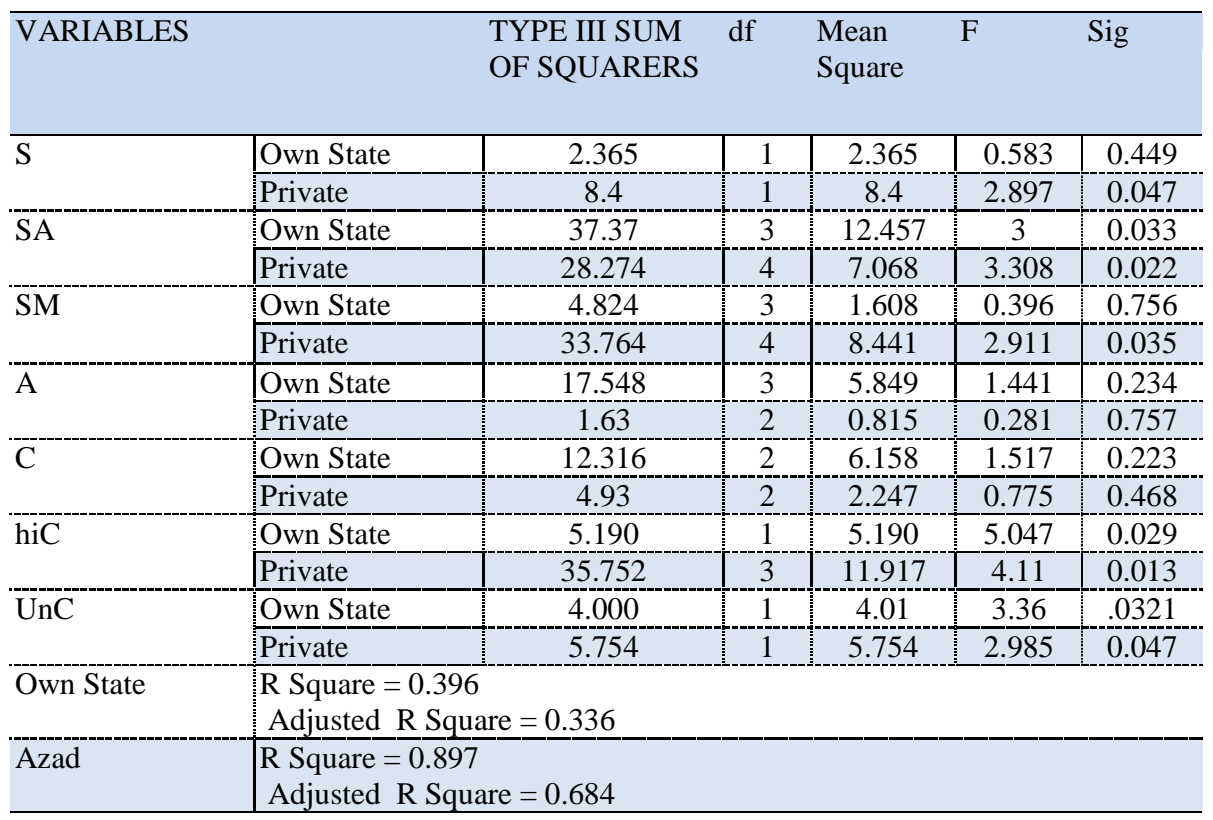

dependent variable: principles of accounting score

Results in Table 4 show, shows in own state university self confidence in accounting $(0.033)$, high school course $(0.029)$, university course $(0.0321)$ have significant affect on principles of accounting score and in private university $\operatorname{sex}(0.047)$, self confidence in accounting $(0.022)$, self confidence in mathematics (0.035), high school course (0.013), have significant affect on principles of accounting score. 
As figure1 shows Mathematics course in high school has the highest score, and empirical, human, technical courses respectively have lower scores.

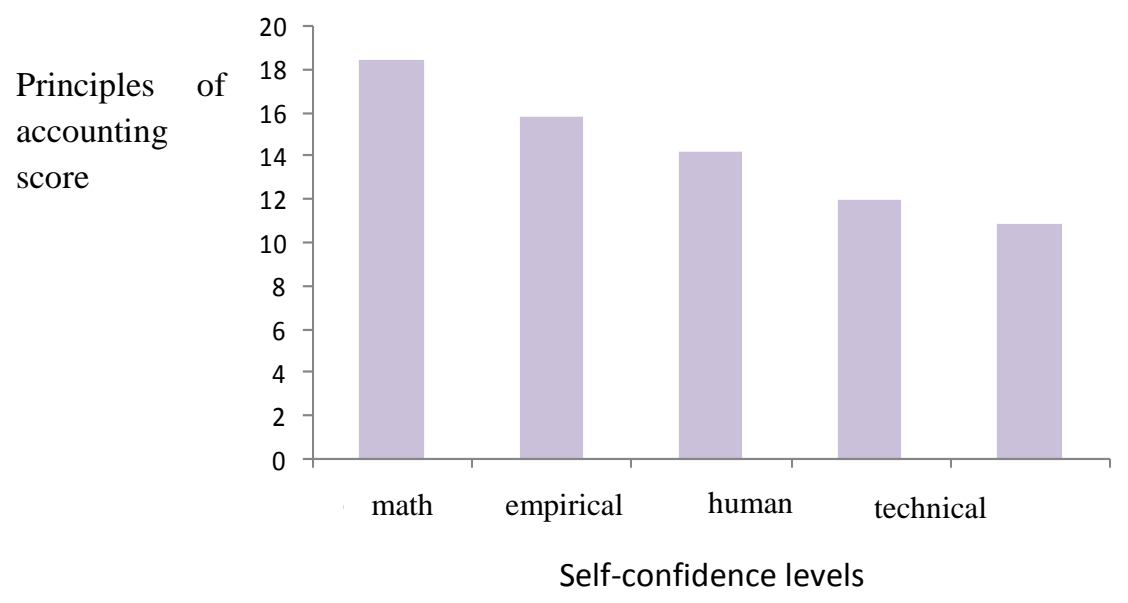

Figure 1. High school courses affect on principles of accounting score

As figure 1 shows students, who was their high school mathematics achieved the highest score in principles of accounting. Because in this field students pass more mathematics units than others. In sequence as students pass lower mathematics units in high school, they give lower score in principles of accounting.

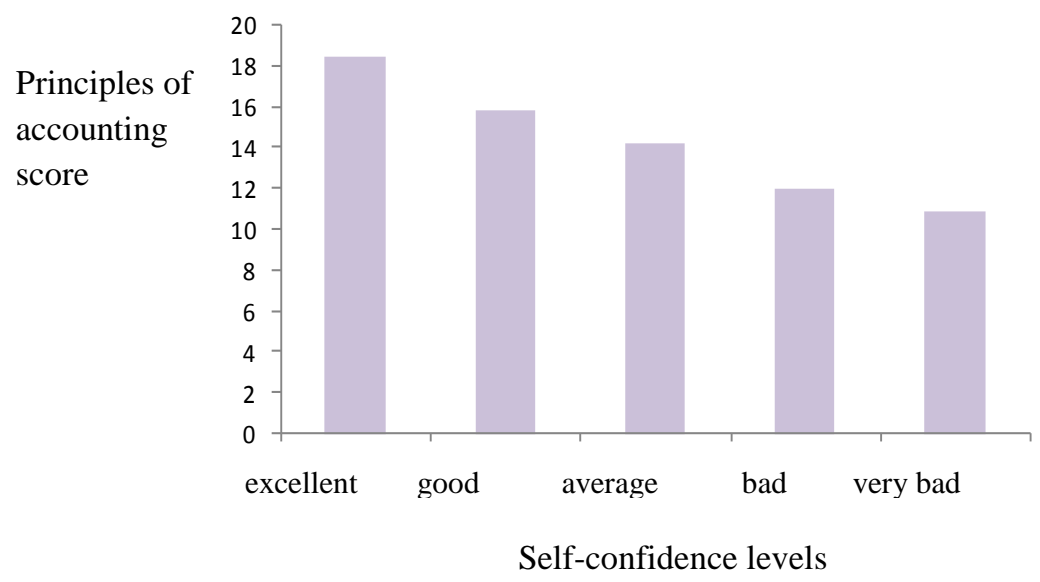

Figure 2. Self-confidence levels affect on principles of accounting score 
As figure 2 shows students who had the higher level of self-confidence got the better scores in principles of accounting lesson. As the level of selfconfidence, decrease students give lower score.

Table5 shows in own state university estimation of incremental explanatory power of mathematics course and demographic variables that $\mathrm{R}$ square equals 0.379 and in private university R-square equals 0.49 also shows general linear model's results equation as below: $\mathrm{UnC}$

MScore $=\beta 1+\beta 2 \mathrm{G}+\beta 3 \mathrm{SA}+\beta 4 \mathrm{SM}+\beta 5 \mathrm{~A}+\beta 6 \mathrm{C}+\beta 7 \mathrm{hiC}+\beta 8$

Mscore $=$ mathematics score

According table5, in own state university self confidence in mathematics and high school course and in private university self confidence in mathematics, high school course and university course have a significant effect on math score then can be resulted when students have the higher level of self confidence, they will give the better score in mathematics, as well as students who their field in high school were mathematics achieved better results.

Table 5. Demographic variables affect on mathematics score

\begin{tabular}{|c|c|c|c|c|c|c|}
\hline VARIABLES & & $\begin{array}{l}\text { TYPE III SUM OF } \\
\text { SQUARERS } \\
\end{array}$ & $\mathrm{df}$ & $\begin{array}{l}\text { Mean } \\
\text { Square }\end{array}$ & $\bar{F}$ & Sig \\
\hline \multirow[t]{2}{*}{ S } & Own State & 2.66 & 1 & 2.66 & 0.499 & 0.481 \\
\hline & Private & 3.251 & 1 & 3.251 & 0.68 & 0.415 \\
\hline \multirow[t]{2}{*}{ SA } & Own State & 34.303 & 3 & 11.434 & 2.143 & 0.098 \\
\hline & Private & 19.079 & 4 & 4.77 & 0.998 & 0.422 \\
\hline \multirow[t]{2}{*}{ SM } & Own State & 4.342 & 3 & 8.447 & 6.271 & 0.046 \\
\hline & Private & 29.833 & 4 & 5.458 & 3.56 & 0.027 \\
\hline \multirow[t]{2}{*}{ A } & Own State & 2.719 & 3 & 0.906 & 0.17 & 0.917 \\
\hline & Private & 8.382 & 2 & 4.191 & 0.877 & 0.425 \\
\hline \multirow[t]{2}{*}{$\mathrm{C}$} & Own State & 12.316 & 2 & 6.158 & 1.517 & 0.223 \\
\hline & Private & 4.493 & 2 & 2.247 & 0.775 & 0.468 \\
\hline \multirow[t]{2}{*}{ hiC } & Own State & 3.307 & 2 & 7.653 & 5.31 & 0.034 \\
\hline & Private & 58.183 & 3 & 19.394 & 4.057 & 0.014 \\
\hline \multirow[t]{2}{*}{$\mathrm{UnC}$} & Own State & 36.75 & 1 & 36.75 & 6.889 & 0.01 \\
\hline & Private & 0.058 & 1 & 0.058 & 0.012 & 0.913 \\
\hline Own State & \multicolumn{6}{|c|}{$\begin{array}{l}\text { R Square }=0.426 \\
\text { Adjusted R Square }=0.379\end{array}$} \\
\hline Private & \multicolumn{6}{|c|}{$\begin{array}{l}\text { R Square }=0.533 \\
\text { Adjusted R Square }=0.49\end{array}$} \\
\hline
\end{tabular}

Dependent variable: mathematics score 
Table 6 shows estimation of incremental explanatory power of principles of accounting course with demographic variables and math score in own state university equals 0.557 and in private university equals 0.761 also shows general linear model's results as below: $\beta 9 \mathrm{MScore}$

PScore $=\beta 1+\beta 2 \mathrm{G}+\beta 3 \mathrm{SA}+\beta 4 \mathrm{SM}+\beta 5 \mathrm{~A}+\beta 6 \mathrm{C}+\beta 7 \mathrm{hiC}+\beta 8 \mathrm{UnC}+$

Table 6. Demographic variables and mathematics score affect on principles of accounting score

\begin{tabular}{|c|c|c|c|c|c|c|}
\hline VARIABLES & & $\begin{array}{l}\text { TYPE III SUM } \\
\text { OF SQUARERS }\end{array}$ & df & $\begin{array}{l}\text { Mean } \\
\text { Square }\end{array}$ & $\mathrm{F}$ & Sig \\
\hline \multirow[t]{2}{*}{$S$} & Own State & 1.130 & 1 & 0.130 & 0.530 & 0.468 \\
\hline & Private & 0.008 & 1 & 0.008 & 0.005 & 0.945 \\
\hline \multirow[t]{2}{*}{$\mathrm{SA}$} & Own State & 11.184 & 3 & 3.728 & 2.749 & 0.05 \\
\hline & Private & 33.485 & 4 & 8.371 & 5.188 & 0.002 \\
\hline \multirow[t]{2}{*}{$\mathrm{SM}$} & Own State & 6.838 & 3 & 2.279 & 1.069 & 0.365 \\
\hline & Private & 21.618 & 4 & 5.405 & 3.35 & 0.021 \\
\hline \multirow[t]{2}{*}{ A } & Own State & 1.78 & 3 & 0.593 & 0.278 & 0.841 \\
\hline & Private & 7.207 & 2 & 3.603 & 2.233 & 0.123 \\
\hline \multirow[t]{2}{*}{$\mathrm{C}$} & Own State & 4.05 & 2 & 2.025 & 0.954 & 0.388 \\
\hline & Private & 6.006 & 2 & 3.003 & 2.306 & 0.117 \\
\hline \multirow[t]{2}{*}{$\mathrm{hiC}$} & Own State & 5.26 & 2 & 3.63 & 2.234 & 0.045 \\
\hline & Private & 34.294 & 3 & 11.431 & 7.085 & 0.001 \\
\hline \multirow[t]{2}{*}{$\mathrm{UnC}$} & Own State & 1.278 & 1 & 1.278 & 0.6 & 0.44 \\
\hline & Private & 4.336 & 1 & 4.336 & 0.00 & 0.996 \\
\hline \multirow[t]{2}{*}{ MSCORE } & Own State & 260.859 & 1 & 260.859 & 122.39 & 0.00 \\
\hline & Private & 19.41 & 1 & 19.41 & 12.031 & 0.001 \\
\hline Own State & \multicolumn{6}{|c|}{$\begin{array}{l}\text { R Square }=0.692 \\
\text { Adjusted R Square }=0.557\end{array}$} \\
\hline Private & \multicolumn{6}{|c|}{$\begin{array}{l}\text { R Square }=0.924 \\
\text { Adjusted R Square }=0.761\end{array}$} \\
\hline
\end{tabular}

Results in Table 6 shows in own state university self-confidence in accounting, high school course and mathematics score and in private university self confidence in accounting, self confidence in mathematics, high school course and mathematics score have a significant effect on principles of accounting score. Based on statistical results are presented in Table 6 can be concluded mathematics abilities have affected on understanding in principles of accounting. Mathematics score also have a significant effect on principles of accounting score. Students who had the higher level of self-confidence got the better scores. 
Table 7 shows in own state university estimation of incremental explanatory power of principles of accounting course and math pre-test that $\mathrm{R}$ square equals 0.326 and in private university $\mathrm{R}$ square equals 0.736 , also shows general linear model's results as below: $+\beta 9 \mathrm{MP}$

$\mathrm{PScore}=\beta 1+\beta 2 \mathrm{G}+\beta 3 \mathrm{SA}+\beta 4 \mathrm{SM}+\beta 5 \mathrm{~A}+\beta 6 \mathrm{C}+\beta 7 \mathrm{hiC}+\beta 8 \mathrm{UnC}$

MPScore $=$ math pre-test score

Table 7. Demographic variables and mathematics score affect on principles of accounting score

\begin{tabular}{|c|c|c|c|c|c|c|}
\hline VARIABLES & & $\begin{array}{c}\text { TYPE III } \\
\text { SUM OF } \\
\text { SQUARERS }\end{array}$ & df & $\begin{array}{l}\text { Mean } \\
\text { Square }\end{array}$ & $\mathrm{F}$ & Sig \\
\hline \multirow[t]{2}{*}{$S$} & Own State & 0.002 & 1 & 0.002 & 0.000 & 0.983 \\
\hline & Private & 0.011 & 1 & 0.011 & 0.006 & 0.937 \\
\hline \multirow[t]{2}{*}{$\mathrm{SA}$} & Own State & 40.627 & 3 & 13.542 & 3.259 & 0.024 \\
\hline & Private & 32.275 & 4 & 8.069 & 4.519 & 0.005 \\
\hline \multirow[t]{2}{*}{$\mathrm{SM}$} & Own State & 3.061 & 3 & 1.02 & 0.246 & 0.864 \\
\hline & Private & 11.281 & 4 & 2.82 & 1.58 & 0.203 \\
\hline \multirow[t]{2}{*}{$\mathrm{A}$} & Own State & 4.14 & 3 & 1.38 & 0.332 & 0.802 \\
\hline & Private & 4.583 & 2 & 2.291 & 1.283 & 0.291 \\
\hline \multirow[t]{2}{*}{$\mathrm{C}$} & Own State & 13.153 & 2 & 6.577 & 1.804 & 0.169 \\
\hline & Private & 4.437 & 2 & 2.219 & 1.521 & 0.235 \\
\hline \multirow[t]{2}{*}{ hiC } & Own State & 1.803 & 2 & 0.902 & 0.217 & 0.805 \\
\hline & Private & 63.028 & 3 & 21.009 & 11.768 & 0.00 \\
\hline \multirow[t]{2}{*}{ UnC } & Own State & 22.572 & 1 & 22.572 & 5.432 & 0.021 \\
\hline & Private & 0.002 & 1 & 0.002 & 0.001 & 0.974 \\
\hline \multirow[t]{2}{*}{ MPSCORE } & Own State & 3.796 & 1 & 3.796 & 0.914 & 0.341 \\
\hline & Private & 13.737 & 1 & 13.737 & 7.694 & 0.009 \\
\hline Own State & \multicolumn{6}{|c|}{$\begin{array}{l}\text { R Square }=0.4 \\
\text { Adjusted R Square }=0.326\end{array}$} \\
\hline Private & \multicolumn{6}{|c|}{$\begin{array}{l}\text { R Square }=0.916 \\
\text { Adjusted R Square }=0.736\end{array}$} \\
\hline
\end{tabular}

Results in Table 7 shows math pre-test score does not has significant affect on Principles of accounting score in own state university while self confidence in accounting and university course have significant affect on Principles of accounting. In private university math pre-test score, selfconfidence in accounting, high school course have a significant effect on principles of accounting score. 


\section{CONCLUSION AND SUGGESTIONS}

The main purpose of this research is exploration of math abilities that affect on understanding in principles of accounting via exploring mathematics score and math pre-test score that includes various areas of mathematics (arithmetic, percentages and proportions, algebra operations and conceptions) on students' performance in principles of accounting course. Arithmetic, percentages and proportions, algebra operations and conceptions are composed of eight questions and conception consists of nine questions. Results shows students have highest skill in arithmetic (own state $92.5 \%$, private $56.3 \%$ ) and own state university's student got the lowest score in conceptions that consist of 2 arithmetic questions, 4 percentages and proportions questions, 3 algebra questions that indicate students have highest weakness in this matter (64\%) but in private's student had the lowest score in algebra (40\%).

In addition, research's results showed mathematics skills affect on understanding in principles of accounting course as a key factor of successful in accounting course. Another factor that would affect on understanding in principles of accounting are considered gender, age, high school course, university course and self confidence. In order to fulfill this goal a questionnaire was given to students that is consist of 3 part and contain demographic information, high school course and self confidence, math pre-test. For responding to this questionnaire was considered 25 minutes time and students were not allowed to use of calculator. Statistical sample consist of 184 own state university's students and 105 private university's students who had selected principles of accounting lesson.

First, affects of demographic variables on principles of accounting course and mathematics score was explored, in order to achieve this goal was applied general linear model to explore affect of independent variables on accounting course in own state and private university. Self confidence in accounting, high school course and university course and mathematics score had a significant effect on understanding in principles of accounting in own state university and self confidence in accounting, high school course, self confidence in mathematics, mathematics score and math pre-test score had a significant effect on understanding in principles of accounting in private university. For exploring relationship among demographic variables were applied chi square test, results showed student who had a high level of self confidence achieved better score, and students who was their high school course mathematics got the highest score and the lowest scores were empirical, human and technical courses respectively. In generally, female had better scores and accounting course achieved the best results and 
students who were in the higher class their scores better than others because of more skills in accounting and mathematics. According to this research mathematics score has a significant effect on principles of accounting score, math pre-test score also has a significant effect on principles of accounting score in private university.

Based on results of this research in order to increase quality level of accounting education some suggestions are presented as below:

1) Mathematics abilities should be considered and attempted for promoting it.

2) Passing more mathematics units in first semester specially for students who have less ability in mathematics with considering their high school course.

3) Quality level increasing in accounting and mathematics education in order to promote students self-confidence.

4) performing investigation for exploring affect of English language learning on understanding in principles of accounting.

\section{REFERENCES}

Alcock, J. Cockcroft, S. and Finn, F. (2008). Quantifying the advantage of secondary school mathematics study for accounting and finance undergraduates, Accounting and Finance, 481, 697-718.

Ballard, C L., Johnson, MF (2004). Basic Math Skills and Performance in an Introductory Economics Class, Journal of Economic Education 35(1): 3-23.

Gary, N. (2008). Marks Accounting for the gender gaps in student performance in reading and mathematics: evidence from 31 countries Oxford Review of Education, Vol. 34, No. 1, pp. 89-109.

Meelissen, M., Luyten, H., (2008). The Dutch gender gap in mathematics: small for achievement, substantial for beliefs and attitude Studies in Educational, 34, pp. 82-93.

Pritchard, R E., Romeo, GC, Saccucci, MS. (2000). Quantitative skill and Performance in Principles of Finance: Evidence from a Regional University, Financial Practice and Education 10 (2): 167-174.

Rainsbury, E., Darroch, A. (2009). Accounting and Finance Association of Australia and New Zealand Conference, 5 -7.

Warsono, S., Darmawan, A., Arsyadi Ridha, M. (2009). Using Mathematics To Teach Accounting Principles. Accounting Principles, Volume 1 Chapters 1-13, Second Edition.

Yunker, P J., Yunker, JA., Krull, GW. (2009). The influence of mathematics ability on performance in principles of accounting. The Accounting Educations Journal Volume Xix pp.1-20. 